\title{
Public Rendition of Authorship: Commemorative Ceremonies in Neo-Avant-Garde Projects by Zabludovsky-Zorica
}

Marina Protrka Štimec

University of Zagreb, Faculty of Humanities and Social Sciences, Ivana Lučića 3, 1000 Zagreb, Croatia

https://orcid.org/0000-0002-3764-5625

mprotrka@ffzg.hr

Artistic intermedial and interdiscursive projects and performance art events on the artistic stage written by Željko Zorica and his imaginary co-initiator "paleoanthropologist, demonologist, card player and wine drinker, Hans Christian Zabludovsky, PhD" are based on commemorative practices established by historical science and culturology. They refer to mechanisms of history production, question creative processes and evaluate the elusive and complex relationship between collective memory, the political sphere, literature and history. Zorica-Zabludovsky's books and artistic performances (the erection of memorial plaques in Paris, Zagreb and Oporovec) challenge the "social imaginary" as a fundamental reference of historiographical and critical work, demonstrating that theoretically and politically conscious art does not necessarily interfere with aesthetic experience. This paper analyses them as expression of the transgressive character of post-avant-garde artistic practices — as undertakings that reveal the basic relationship between art, literature, history and public space.

Keywords: visual arts / post avant-garde / performance / cultural engagement / public commemorations / collective memory / Zorica, Željko

Public commemorative ceremonies ruled the public space of European countries in the eighteenth and the nineteenth century, at a time when national literatures took form and historical sciences, humanist approaches and methods were established. ${ }^{1}$ As part of the process of "imagining a nation" (Anderson 6) of that time these public gather-

${ }^{1}$ This paper is part of ongoing research project Literary revolutions, funded by Croatian Science Foundation (LIRE IP-2018-01-7020). 
ings offered an opportunity to a large number of people to participate, experience and demonstrate in public their feeling of belonging to a collective. This collective, unlike previous ones, which were localized linguistically and in terms of customs and religion, was more abstract and more difficult to compare. Public commemorative ceremonies included the participation of prominent individuals and groups, as well as a large number of citizens, processions of their associations following a protocol, a pageant, wreath-laying at monuments, repetition of certain symbolic scenes, "live pictures," poetic competitions, illuminations, "apotheoses," exchanges of telegrams with like-minded individuals from other locations, and finally banquets and toasts (Leerssen and Rigney 15; Dović, "Model"; Dović, Kulturni). This "fever of centenaries" subsided with the long nineteenth century and, since the mid-twentieth century was channeled through institutional practices in which authorized individuals and groups marked commemorative locations of meritorious great men with, most often, a small number of interested individuals (Protrka Štimec 28-41).

Artistic interest in individual or group performances in a public space appears in neo-avant-garde, post-avant-garde and retro-avantgarde practices that question the mechanisms, functions and interactions of public and private, art and society, past and present, form and contingence. In the late 1960s and the 1970s, artistic performances manifest themselves as "a social turnabout," an attempt at revisiting the collective, which again became topical in the 1990s under the influence of, as Sandra Uskoković points out, a triangle made up of "the narrative of victory, heroic defense and debacle of a collectivist vision of society" (Uskoković 37). As demonstrated by Suzana Marjanić in her systematic overview, Tomislav Gotovac, Sanja Iveković, Vlasta Delimar, as well as groups like "Kugla glumište (The Sphere Theatre)" are active on the Croatian scene of performance art and actionism of the 1960s and 1970 s to the present (see Marjanić). They function as a showcase of a collaboratively devised theatre (Kačić-Rogošić 33), in which the collective quality of work and performance also implies social effectiveness. ${ }^{2}$ "Kugla glumište" performed in public spaces which, at the time, departed from the usual perception of a suitable setting for theatre performances.

2 "Kugla glumište" is a Zagreb theatre group that launched public performances of plays designed by groups in the 1970s and early 1980s. These performances included joint work on determining "the performance's creative goal, methodology of creation and content within an improvising and workshop-like ambiance." In this regard, "social function like the expression, therapy and means of social-political activity of a social group” was important (Kačić-Rogošić 33). 
As Marjanić demonstrated: "Performances were held in squares and at fairs, and cooperation was established with marginal social groups. One counted on action theatre, happenings and sentimental anarchy. At the time, public spaces were still taboo as venues for artistic events, i.e., theatre was played only in real theatres and institutions" (Marjanić 723-737). ${ }^{3}$ The Kugla's collectivism was realized in the neo-avant-garde and Brechtian intention of re-examining the collectivity in the new use of the theatre, which, through its subsequent soft and hard factions, will remain one of the sore spots of the community.

Željko Zorica Šiš (1957-2013) appeared from this context developing his own artistic profile within the Kugla's soft faction. He was a writer, multimedia artist, set designer, layout artist, comic strip artist, puppeteer and director, or, as Nataša Govedić called him, "a complete team for rescuing fantasy" (Govedić). Active in various artistic fields, from literature and theatre to performance art, using film, video, archives, the web, music, food, happenings and design, Šiš was the founder of the theatre groups "Ulješura (Sperm Whale)" and "ZZOT" (1984), "Kačinsky Troupe" (1985) and "Uplašena žirafa (The Frightened Giraffe)" (1987). In the 1980s, he started a lengthy project entitled Digitalization of the Heritage of Monuments and its Commercial Use in which he introduced the figure of a researcher, associate, motivator and friend Hans Christian Zabludovsky, $\mathrm{PhD}$, "a demonologist, paleoanthropologist, card-player and wine-drinker.” Based on Sišs's performances that were staged at the encouragement and in honor of Zabludovsky, as well as his books from the Fantastic Bestiary cycle ${ }^{4}$ in which he presented a biography, discovery of and knowledge about the world of unusual creatures. In this paper I will demonstrate how such

3 "Kugla glumište" usually used suburban venues for their performances, such as a spacious field in the Zagreb neighbourhood Travno, which was not an urban area at the time, where in 1977 they performed Doček proljeća (Welcoming the Spring); Unska Street featuring poor workers' dwellings (Mekani brodovi [Soft Ships], 1977), the Bundek lake, which was not landscaped at the time (Bijela soba na splavi [White Room on a Raft], 1978), the Gradec park in Zagreb or the Lovrijenac park in Dubrovnik (Ljetno popodne ili Što se desilos Vlastom Hršak [A Summer Afternoon or What Happened to Vlasta Hršak], 1980). In doing so, they incorporated art into an active everyday life and thus worked, as Sandra Uskoković emphasised, in two directions: they protected art by expanding it transgressively, and decomposed art by making life artistically more fulfilled (Uskoković 60).

${ }^{4}$ Fantastic Bestiary cycle makes collection of books: Usnuli čuvari grada Zagreba ili Fantasticni bestijarij (Sleeping Guardians of the City of Zagreb or Fantastic Bestiary) (1996), Fantastični bestijarij Roskildea (Roskilde's Fantastic Bestiary) (1999), and Fantastični bestijarij Hrvatske 2 (Croatia's Fantastic Bestiary 2) (2000). 
post-avant-garde artistic practices question and redefine the basic relations between art, literature, history and public space.

\section{Plaques of Fabricated History: Zabludovsky Meets Literary Canon}

Željko Zorica Šiš did his first "commemorative” performance art event dedicated to Croatian writers in Paris, where he placed a plaque on the facade of the alternative cultural club "Les Voutes" on 25 May 2005 commemorating the day when in $1900 \mathrm{H}$. C. Zabludovsky and A. G. Matoš "drank up a bottle of absinthe and together howled against the horrible, dreadful and endless prattle about freedom" (see Figure 1 and 2). As Agata Juniku writes, "herewith, he very precisely touched two raw nerves of the average Frenchman - 'the sacred' French Revolution and the attitude towards foreigners," for which he immediately got "a violent verbal reaction from the next-door neighbor" (Juniku, "Zabludovsky"). Here, one can see another effect of the performance art event, besides the violent reaction of the environment. As early as in these performances, Zorica assumed publicly unquestionable commemoration strategies, which he subsequently reduced on its basic formal structure. They already became interesting at this point because of the effective "formality" when imitating the form and the ceremonial, and because of the way in which he interacted with the authorities. This artistic action also implied applying for funds from the Croatian Ministry of Culture, which proved to be very cooperative until the moment when, in the final stage of talks, the issue was raised about the "actual" existence of Hans Christian Zabludovsky.

\footnotetext{
${ }^{5}$ In an interview given to Agata Juniku, Zorica emphasised: "In Paris, I managed to put up a plaque in honour of Zabludovsky and Matoš thanks to my artistic association Artless. However, both the City and the Ministry declined to give me financial support. Interestingly enough, the Ministry initially approved the project, but declined it just before its realisation since the people there were not sure whether or not Zabludovsky was a historical person from Croatia. They did not pursue the idea of having the opportunity to participate in something that is, I am sure, of historic significance. Croatian culture managed to put up a commemorative plaque there, even if indirectly, in honour of a writer held in high esteem by everyone." (Juniku, "Zabludovsky")
} 


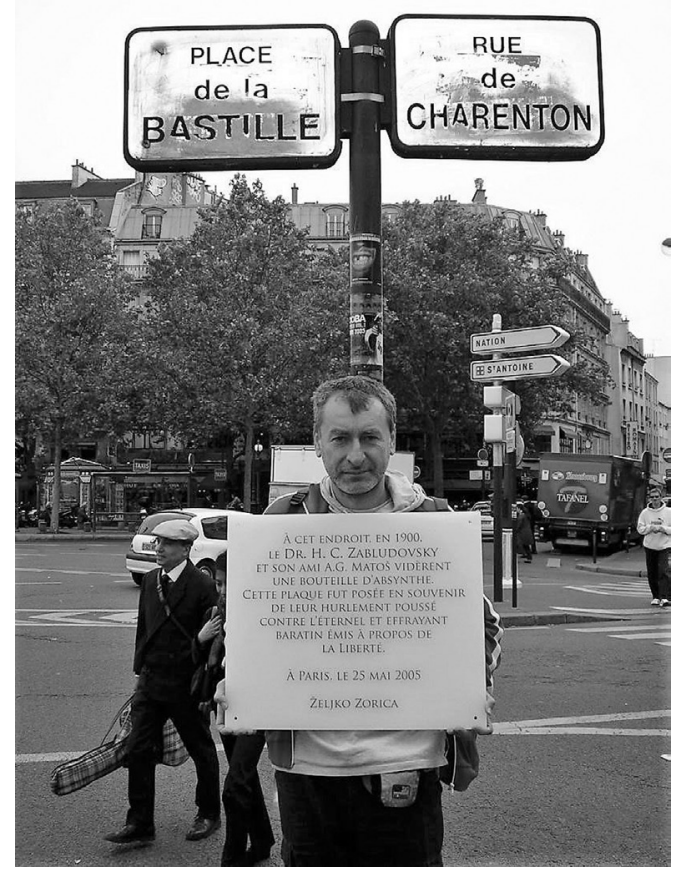

Figure 1: Željko Zorica: In memory of Zabludovsky and Matoš, Paris, 25 May 2005. From a private album.

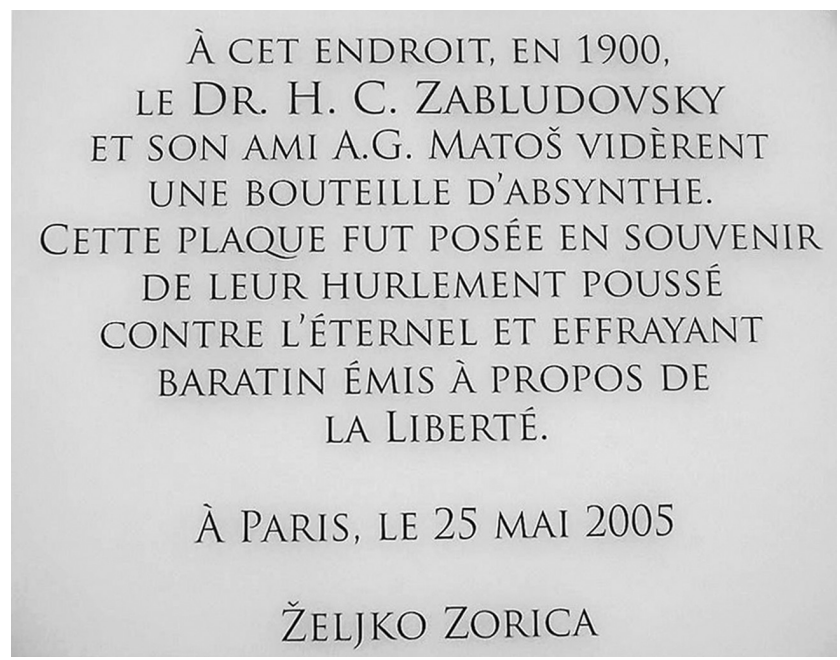

Figure 2: Plaque in honor of Zabludovsky and Matoš who "drank up a bottle of absinthe and together howled against the horrible, dreadful and endless prattle about freedom." From a private album. 
An analogous event took place in 2002 when a performance art event entitled "Let History Talk Vol. II" was staged as part of the Urban Festival in Zagreb. It was entirely dedicated to Zabludovsky and announced with the following words: "Putting up this commemorative plaque on the facade of a house in Šestinski dol no. 65b in Zagreb, Željko Zorica and the Urban Festival will rectify historical injustice, which has been done for many years to this great man, Croatian scientist and artist, who is exceptionally appreciated in the world." On that occasion Zorica managed to gain confirmation from the authorities:

\begin{abstract}
The Speaker of Parliament at the time, Zlatko Tomčić, sent his regrets in an official letter, since it was quite clear to him that this was a very important cultural and scientific potential of Croatia. We continued the process of reaffirming Zabludovsky's existence on the cultural map of Europe by unveiling a commemorative plaque in Paris, where for the first time I began to involve important personalities from Croatian history. Later on, we discovered Zabludovsky's connections to certain prominent people from world culture. This is neat because it is a method that relaxes people. The ultimate goal is to achieve Zabludovsky's admission to the Croatian Academy of Sciences and Arts. Should this ever occur, it will prove that we live in a normal and relaxed society that does not produce stressful situations making people get malignant diseases because they are worried. Then, I am certain, we shall all be jolly and positive energy will radiate around us in the sense of this guarded crescent of ours. (Juniku, "Zabludovsky")
\end{abstract}

The series of links between Zabludovsky and great men of Croatian culture and history after Matoš continued with a plaque placed in honor of Vladimir Nazor, Ivan Goran Kovačić and Zabludovsky. The event was performed as part of the program of Queer Zagreb Festival. The plaque read, as shown in Figure 3: "At the dawn of a war and at the provocation of Hans Christian Zabludovsky, centaur Ivan Goran Kovačić met here satyr Vladimir Nazor. Remember, you, chance traveler, their cry for the dear intoxicating freedom! Zagreb, 12 May 2007. Željko Zorica and Queer Zagreb.” 


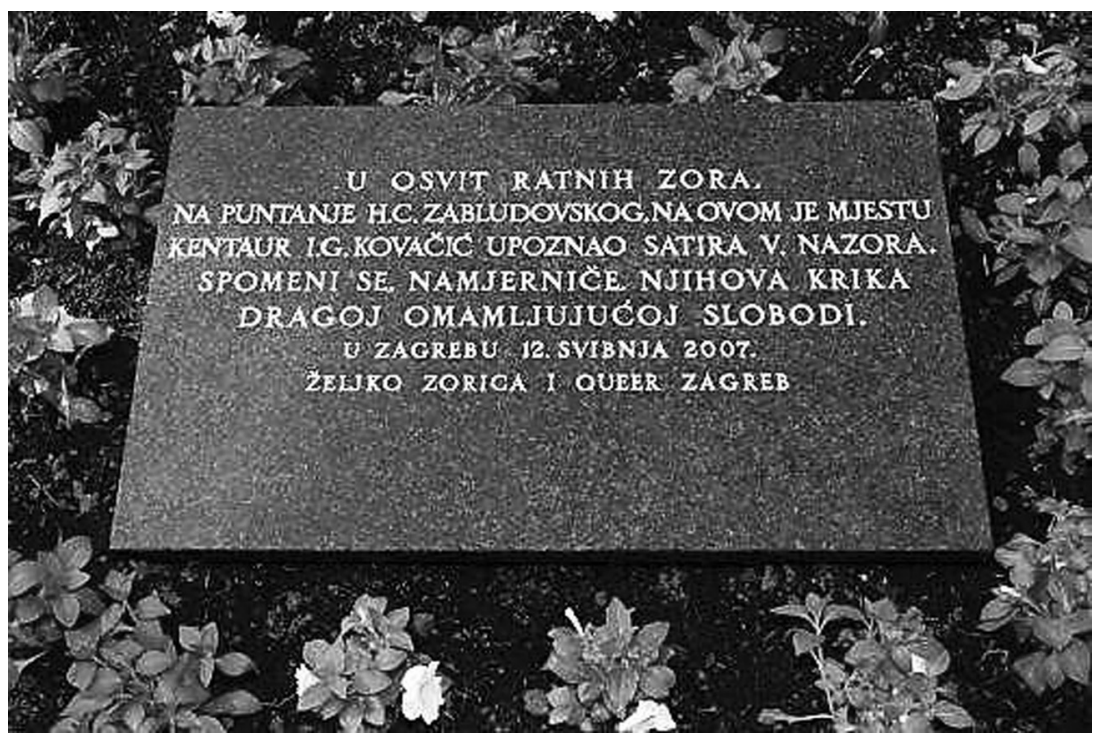

Figure 3: Zorica and Queer Zagreb: Zabludovsky, Nazor and Kovačić: “Remember, you, chance traveler, their cry for the dear intoxicating freedom!,” Zagreb, 12 May 2007.

The placing of this plaque drew public attention since the event was interpreted as some sort of "posthumous outing" of the mentioned twosome (Šišović). In explaining his motivation for the plaque, Zorica emphasized that "we cannot with certainty say anything about the close bond" between Kovačić and Nazor and that—since "their meeting in Zagreb was fatal, both for their private biographies and the history of Croatian literature, and for the famous boat on the Kupa River and Croatian anti-fascism"- -he decided to immortalize these few non-facts by placing a commemorative plaque, which rightly appeared to be scandalous to amateurs and those mindful of the souls of others. The evident and convincing implication of the event was, as demonstrated by Sanja Kajinić, that it called into question the absence of research on the presence of queer in Croatian art (Kajinić 287). After the "Matoš" plaque commemorating the encounter and drinking of absinthe, this plaque confirmed Zabludovsky's provocations and an imaginary romantic encounter at that location. This act, as pointed out by Kajinić, "incarnates the play of the interrelationship between fantasy, performance and (absent) reality" (Kajinić 287). In this case, an immediate reaction from the social subcultures became 
visible in an aggressive incident involving anonymous homophobes demolishing the plaque.

Each such event, as we can see, produces an evident effect in real time, changing thus the nature and understanding of an artistic event. As pointed out by John Burnham, who refers to the work of Hans Haacke:

Traditionally, art-works exist in "mythical time," that is, in an ideal historical time-frame separated from the day-to-day events of the real world. Some systems and conceptual artists, such as Haacke, attempt to integrate their works into the actual events of the "real world," that is the world of politics, money making, ecology, industry, and other pursuits. In effect, the work becomes not only the original concept or piece, but any significant public or official response to it, or any further variations which the work may take as a result of its engagement with the world-at-large. (Burnham 133)

Commemorative events in honor of great men of the past and ceremonial unveiling of plaques that Zorica staged in his public performances act simultaneously as imitations and subversions of customary formalized procedures, their rituality and unquestionableness. In Paris, he allegedly unveiled the plaque for memory's sake, but "also for the sake of historical accuracy that inexorably rectifies bureaucratic short-sightedness and the sluggishness of State institutions" (Zorica, Digitalizacija). Obviously, history needs to be rectified since it passes over in silence evident and significant encounters of $\mathrm{H}$. C. Zabludovsky: with Matoš in Paris, with I. G. Kovačić and V. Nazor on streets that are today named after them-or, subsequently, with Brecht, Duchamp and others.

Zorica's subsequent projects work similarly: they record the existence of H. C. Zabludovsky, his interactions with prominent names of the cultural and literary past, names of great symbolic value andsimultaneously_-are engaged in a specific contemporary social context. In 2005, Zorica continued a series of performance art events that detect and "revive" Zabludovsky's interaction in imaginary historical diachrony and in "real time," as Hans Haacke asserted it in his work (Burnham 133), by placing a plaque on the building of the Zagreb Badel wine and spirits producer. The plaque records Zabludovsky's support for the conversion of the premises and the establishment of a center for independent culture and youth. In 2009, another plaque marked the meeting of Zabludovsky and Bertolt Brecht who, under the motto "Do not give up on what does not exist!," supported the students from the Faculty of Humanities and Social Sciences in Zagreb in their struggle for free education (see Figure 4). Finally, in 2011, 
on the occasion of the celebration of the sixtieth anniversary of the beginning of bocce in the Zagreb neighborhood of Oporovec, a multimedia plaque was unveiled honoring $\mathrm{H}$. C. Zabludovsky as the first bocce player.

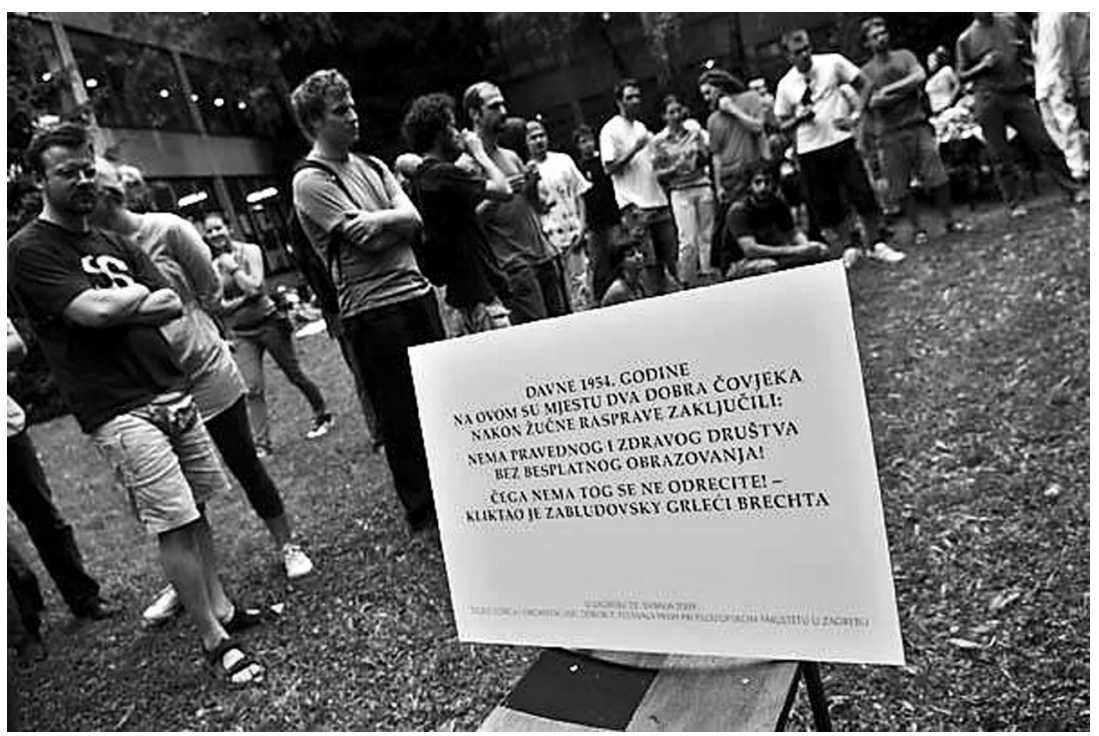

Figure 4: Zabludovsky and Brecht support free education: "Do not give up on what does not exist!"

The event staged in the Oporovec neighborhood denoted a step further in a more explicit evocation of memorial celebrations that were held under the motto "Happiness of an Individual-Success of a Collective," with the note "The menu was prepared according to instructions of the "chef Bertolt Brecht" (Zorica, "Događaj"). In this performance art event, the level of fictionalization is further emphasized since a marble commemorative plaque was replaced this time with a flat TV screen broadcasting the picture of a plaque. This "prototype of the first electronic commemorative plaque" was put up with the motto "Let us support fabricated history." The plaque was unveiled at a public happening that included the customary commemorative ceremonial: a brass orchestra played the national anthem, a local folklore group performed, a flag, an impressive speech and the anthem.

As on earlier occasions, the introductory speech gives emphasis to the performance. Zorica underlines its social and artistic structure: 
"This commemorative plaque gives importance to our everyday life and warns the powerful ones that the life of us, down here, is equally important." (Zorica, "Događaj") The inscription on the plaque again imitates the usual content of a monument inscription: "Commemorating the beginnings of bocce in Oporovec... in honor of Zabludovsky who introduced bocce balls from the south..." On the other hand, and as Zorica stressed, the medium used, the electronic simulation of a marble plaque, aims at a new level of reflection by the participants: it instructs them to raise their awareness and change their way of thinking "about the significance of monumental sculpture" (Zorica, "Događaj"). It also invites: "Let us stop having illusions about an artistic, cultural and social engagement that rests on a continuous study of the relation between the real and the fictitious. Let us stop having illusions about frequently unclear borders between reality and historical fabrications. Let us support fabricated history. Yes! We know what tomorrow will bring. And how about you?!” (Zorica, "Događaj”).

This explanation of "Brecht's cuisine" in the post-avant-garde manner implying repeated use of the form and universalistic resistance to the homogenization of culture and public space may best round off Zorica's art project realized under the patronage of and in cooperation with Zabludovsky. In 2011 at the Noć performansa (Performances Night) in Belgrade, and in LaMaMa in New York, Zorica gave a performance entitled Digitalization of the Heritage of Monuments and its Commercial Use in which he referred to his work and cooperation with Zabludovsky that had been ongoing since 1983. The project description read:

Zabludovsky has been trying for many years to comprehend the commercial value of monumental plastic and commemorative plaques that are mostly owned by cities, on whose building facades they are usually placed. As noted by Zabludovsky, people very rarely stop to read what is actually written on these commemorative plaques. Then, an idea occurred to him, and Zorica is its follower, to arrange the lease of commemorative plaques in agreement with the rightful owners. To that end, an option was given to replace awkward and heavy stone or metal plaques with light monitors that will, for a certain period of time, broadcast texts or picture material referring to a person or event that the plaque honors. The whole project will develop from the center of a company to be established that will manage the full deal. (Zorica, Digitalizacija)

Homogenizing strategies of either a national State or companies, cities, media and masses, individuals who rarely stop remain recognizable 
in Šišs performances. The role therein played by Zabludovsky will be clearer if one considers accompanying publications: bestiaries as biographies and redefined city landscapes.

\section{Zabludovsky_-Driving Force, Intermediary in Dichotomies}

Interdiscursive projects, books of prose by Željko Zorica Fantastični bestijarij Roskildea (1999) and Fantastični bestijarij Hrvatske (2000), created in cooperation with Zabludovsky and following Usnuli čuvari grada Zagreba (1996) reflect the scope and meaning of the aforementioned public performances. Commenting the publications of these two authors(!), Krešimir Bagić believes that their basic idea is

that we are in constant contact with fantastic beings, that they surround us, moreover that we-unknowingly-communicate with them. Demons, dragons, gargoyles silently observe us from the facades of cathedrals and churches, they struggle with the dust on the lintels of various buildings, wells, in flyers and inserts, newspaper ads, cooking recipes... (Bagić)

With his stories about Zabludovsky's undertakings and related discoveries, Zorica draws our attention to "the share of the fantastic in our lives," motivating us to actively communicate with the space in which we move or, at least, to be conscious in that space. According to Bagić, the evocative and interdiscursive type of prose that Zorica writes refers to the totality of the perception that wittily includes different narratives and roles, and in doing so "the reader becomes engaged in the text to the extent that they begin to function as one of its more discreet inhabitants" (Bagić).

This active communication with readers and spectators, or participation in the event or the story, links both of these spheres or media-literature and performance. However, they are also connected by the way that the framework of specifically artistic activity as well as the scope of the broadest public activity is created and treated, including the one we participate in through our own private actions or non-actions.

Zabludovsky introduces himself first by name and description that indicate a mockery of scientific discourse and institutional framework: he is a doctor of old knowledge, "paleoanthropologist and demonologist," but also one who reverses or ridicules this order: "card-player and wine-drinker." He demonstrates this ambivalence by imitating verifiable and objective scientific discourse which he uses to describe unveri- 
fiable, fantastic phenomena and events. His name, which is in collision with his title, ${ }^{6}$ also produces some sort of anxiety or at least the need for great precaution in accepting what he presents to us. Thus, generating questions instead of answers, imagination instead of passive appropriation, Zabludovsky directs the reader-spectator to their own inclusion, their partaking in the production of a story and the truth. Whether you believe it or not, whether you stay on the sidelines or join in-you are part of the common framework of a story, which means that you already are or will soon be misled. To small extent, Zabludovsky is the one who introduces himself in the books as an intermediary, the one between father and a son (Zorica, Usnuli 4), i.e., as a driving force, who blows where he chooses (as in Bible, Jn 3.8: "The wind blows where it chooses"), but also as one who misleads and questions, provokes you, putting you in the position of a responsible or at least a conscious acceptance of delusion.

As a fictitious co-author and mysterious great man of literature, art and culture, Zabludovsky generates a certain kind of memory, refers to the strategies in institutional and public codes of commemoration and memory. He uses imitation and betrays a ritualization of these practices, carrying on neo-avant-garde strategies of taking over and reversing procedures and canons. Brecht is therefore Zorica's continuous reference, in the books and on the streets. "Kugla glumište," as demonstrated by Višnja Kačić-Rogošić, almost realized "Brecht's vision of society in which the material of major education science can be offered since "the difference between studying (instruction) and entertainment, work and leisure, production and enjoyment is abolished" (Kačić-Rogošić 166-167). In line with this point of view, the "rectangular" separation of the stage from the spectators is abolished and the audience is included. Neo-avant-garde aspirations, which are part of it, open a new chapter in understanding the institution of literature. According to Andrea Fraser:

From 1969 on, a conception of the "institution of art" begins to emerge that includes not just the museum, nor even only the sites of production, distribution, and reception of art, but the entire field of art as a social universe. In the works of artists associated with institutional critique, it came to encompass all the sites in which art is shown - from museums and galleries to corporate offices and collectors' homes, and even public space when art is installed there. (Fraser 14)

${ }^{6}$ In Croatian, the name Zabludovsky suggests one who "je u zabludi," i.e., "is misled" thud in contrast to his academic status connoted with his $\mathrm{PhD}$ degree. 
Zorica's interest in plastic arts in museums and public commemorative ceremonies, prepared by his earlier engagement in "Kugla glumište" and intellectually organized in the aforementioned publications participates in a redefinition of the artistic as well as in the public debate on socially relevant themes with a double effect. Using the recognizable ceremonial form of unveiling commemorative plaques in his performance arts events, his work follows two directions:

1. He refers to recognizable strategies of commemorative ceremonies, their predictability, theatricality and fabrication. Also, he imitates public speeches and gestures when unveiling commemorative plaques, unmasks the mythology they produce in a self-explanatorily manner, hiding behind an ostensibly neutral formal speech;

2. He treats the politics of "truth production," "delusion about frequently unclear borders between reality and historical fictions," in such a way that he consciously places them on the scene by emphasizing them with an additional invitation "Let us support fabricated history" (e.g. in Oporovečki vinogradi Street).

Happenings involving fabricated history and neo-avant-garde practices like these usually indicate the transgressive aspect of public performances. In relation to contemporary art these are subversive actions whose objective is to

provoke, challenge or overcome in a transgressive manner the dominant social, cultural or political position of "power," "identity hegemony" or canon politics-aesthetics. [...] Avant-garde transgressions are aberrations (subversions, overstepping, disruptions, breakthroughs, innovations, experiments, revolutions, excesses, destructions) in relation to the dominant ruling hierarchies in art, culture and society. (Šuvaković 118-119)

In contemporary arts, transgressions often form a gap between the artistic and the daily, questioning the certainty and legitimacy of meaning. When it comes to collective celebrations (la fête), such as commemorative ceremonies, as noted by Georges Bataille, "societies themselves exceed the borders of rational, everyday conduct, led by identification, profit, production of goods and self-preservation of the individual and the community" (Šuvaković 119). After the 1960s, transgression was frequently channeled into its own parody.

During the 1990s, and especially in the performing arts, a link was established between reconceptualizing participative arts with their predecessors: historical avant-garde of the early twentieth century, neo-avant-garde of 1968 which in East European countries, as noted 
by Sandra Uskoković, is partially linked to the experience of neoliberal forms of capitalism (Uskoković 37). On the one hand, these experiences usurped former public venues and freedoms, and, on the other hand, generated a series of nationalistic processes of vertical urban development and reconstructed national histories. Agata Juniku analyses related practices in the theatre of Dragan Živadinov and Gledališče sester Scipion Nasice (Scipion Nasice Sisters Theatre) (Juniku, Indos 171). They were oriented towards an artistic production of the new reality. Using propaganda and manipulation strategies, ${ }^{7}$ they referred to their corrupt impact in the public sphere. In this context, one can interpret performance art events by Željko Zorica Šiš, an artist who developed his sensibility through public happenings of "Kugla glumište," marked by elements of socially conscious exploration of space, ridicule, multimedia insertions and medieval theatre. The process of becoming aware of belonging to a community, the role of the body, synergic force of group performances and public spaces from this earlier stage is now, in Zorica's case, seen in a new way in which collective cohesion, mechanisms of remembrance, identification and affiliation are organized: "Members of Kugla glumiste got acquainted with the activities of the Situationists and psychogeography in the 1970s, introducing them in their work as a new consciousness of urban landscape, where the influence of the landscape on individuals' emotions and behavior becomes an essential determinant in spatial thinking." (Uskoković 56) Their appearances, like Zorica's subsequent ones, are on the track of the "détournements" of the Situationists that equally avoid rational criticism (in line with Debord's evasion of rational arguments in criticism, Uskoković 56)

\footnotetext{
${ }^{7}$ In a radio interview to Agata Juniku in 2005, Vladimir Stojsavljević refers to Živadinov's play "Krst pod Triglavom (Baptism Below Triglav)" in which the act of "putting up a plaque" at the foot of the Triglav Mountain was performed. This event also included a specific use of marketing: "They dialled thousands of phone numbers, throughout Yugoslavia, to tell people that the premiere will be on such and such day at such and such time, or to talk to them about art. At one point, they recorded the whole event of unveiling a plaque for 'Krst pod Triglavom' at the source of the Savica River and distributed the recording to the media. People went looking for the plaque, which, of course, did not exist ... What I want to say is they were quite aware of what new media are, what a new approach to advertising products is, including also a cultural product, and that this approach itself changes a cultural product. In other words, they consciously used both mystification and manipulation in order to place themselves on the market of art products at those troubled times, as we would call this today, but also to demonstrate what this manipulation means in ideology." (Juniku, Indoš 171)
} 
and use elements of captivation and play. Therefore, aesthetic interventions and subversions of "Kugla glumište," as seen in the works by Marjanić and Vlašić-Anić (210), revive dead urban spaces, crushing surrealism and politics in a merry destruction of "small pictures of everyday life" (Marjanić and Vlašić-Anić 210). Adapting art into an intense, everyday active life of urban "non-artistic" landscapes and spaces, which was achieved there, can be recognized, as an extended hand, in Zorica's revival of the "sleeping guardians of the city," invisible characters on facades and forgotten doorways. In his books they become parts of identified and re-written stories, in which space and time are contextualized again in a way that they are certified by the authority of timeless Hans Christian Zabludovsky, a person whose scientific domain (demonologist, paleoanthropologist), as well as the semantics of his name and surname refer to the strategies of artistic transgression. The fact that he bears Andersen's name as an author and artistic concept refers to the significance of artistic imagination in the area of knowledge: namely, history, collective perceptions, science, and linear expression. The semantics of the added family name indicate an ironic and subversive presentation of this system of knowledge, linearity, truthfulness or mechanisms of the production of meaning, memory and collective identities whereby serenity and compassion, enjoyment of food, drinks and life are restored in this project of collective "controlled happenings."

Hence, Zorica confirms the thesis of Boris Groys whereby the backbone of avant-garde is not provocation, cynicism or criticism, but rather aesthetic practices with a radical reduction (see Groys). Public commemoration of certain moments of "common everyday life"-in Oporovec: "a commemorative plaque to everyday life," on the occasion of "the beginnings of bocce," on the occasion of the encounter and drinking up a bottle of absinthe-or "Nazor's and Kovačićs cry in honor of the dear intoxicating freedom" can at the same time be considered a use of strategies of linearization and musealization of art and culture, as well as a process of questioning them and reversing the logic of presenting the public as a group of passive recipients. Zorica's project of "considering the commercial value of

${ }^{8}$ A series of performance arts events that are bound together by Zorica's interest in monumental sculpture is most prominently completed by the happening in Oporovec. Today, a series of the author's works on friendship (die Freundschaften) is perhaps best remembered and noted in literature. Most distinguished among them is the one staged on 1 July 2013 at French Republic Square in Zagreb -1.7.2013 ("KroaTischEUFreundschaft") as an alternative celebration of Croatia's accession to the EU. 
monumental sculpture and commemorative plaques on facades of buildings mostly owned by cities" refers at the same time to a sunken "treasure" of cities—space and culture: "As noted by Zabludovsky, people very rarely stop to read what is written on these commemorative plaques." Moreover, this is their repositioning to the elusive durability of the moment. This moment, like "the digital commemorative plaque" from Oporovec, constantly evades petrification. Reappearing on the scene is a living authentic experience which liberates everyday life through imagination and play. In this process, art is protected in a way that it is expanded in order to include transgressive activities. At the same time, the category of art is dissolved during this process to "make life more artistically fulfilled."

\section{WORKS CITED}

Anderson, Benedict. Imagined Communities. New York, NY: Verso, 2006.

Bagić, Krešimir. "Kratka priča devedesetih." Zbornik Zagrebačke slavističke škole. Eds. S. Botica. Zagreb: Filozofski fakultet, 2002. Web. 10. 10. 2021. <http://sveske. $\mathrm{ba/en/content/od-kritickog-mimetizma-do-interdiskurzivnosti>}$

Burnham, Jack. "Steps in the Formulation of Real-Time Political Art." Framing and Being Framed: 7 Works, 1970-75. Ed. Hans Haacke. Halifax; New York, NY: Press of the Nova Scotia College of Art and Design; New York University Press, 1975. 127-143.

Dović, Marijan, ed. “Model kanonizacije evropskih kulturnih svetnikov.” Primerjalna književnost 35.3 (2012): 71-86.

Dović, Marijan. Kulturni svetniki in kanonizacija. Ljubljana: ZRC SAZU, 2016.

Govedić, Nataša. "Uredništvo 'Zareza'." In memoriam - Od Kugle do mnoštva EU križeva. 12. 9. 2013. Web. 10. 10. 2021. <http://www.zarez.hr/clanci/od-kugle-do-mnostva-eu-krizeva>

Groys, Boris. “Towards a New Universalism.” E-flux. Journal \#86. November 2017. Web. https://www.e-flux.com/journal/86/162402/towards-a-new-universalism/

Fraser, Andrea. "From the Critique of Institutions to an Institution of Critique." The Idea of the Avant-Garde And What It Means Today. Ed. Marc James Léger. Manchester: Manchester University Press, 2014. 12-17.

Juniku, Agata. "Zabludovsky vs. Bandić." Kontrapunkt.hr. 12. 09. 2013. Web. 10. 10. 2021. <https://www.kulturpunkt.hr/content/zabludovsky-vs-bandic>

Juniku, Agata. Indoš $i$ Živadinov, teatro-bio-grafije: sveto i ludičko kao modusi političkoga u teatru. Zagreb: Akademija dramskih umjetnosti, Hrvatska sveučilišna naklada, 2019.

Kačić-Rogošić, Višnja. Skupno osmišljeno kazalište. Zagreb: Hrvatski centar ITI, 2017. Kajinić, Sanja. “Queer-kultura u Hrvatskoj: Queer Zagreb Festival.” Kultura, drugi, žene. Eds. Jasenka Kodrnja, Svenka Savić and Svetlana Slapšak. Zagreb: Institut za društvena istraživanja u Zagrebu, Hrvatsko filozofsko društvo Plejada, 2010. 273-289.

Leerssen, Joep, and Ann Rigney, eds. Commemorating Writers in Nineteenth-Century Europe. Basingstoke: Palgrave Macmillan, 2014. 
Marjanić, Suzana. Kronotop hrvatskoga performansa: od Travelera do danas. Zagreb: Institut za etnologiju i folkloristiku, Udruga Bijeli val, Školska knjiga, 2014.

Marjanić, Suzana, and Vlašić-Anić, Anica. "Narušavanje teatra kao kocke. Interview with Zlatko Burić-Kićo." Zarez. 12. 7. 2007: 210-211.

Marković, Igor. “'ZABLUDOVSKY BI TO VOLIO!' Akcije u javnom prostoru Željka Zorice i H.C. Zabludovskog kao re/imaginacija i/ili re/invencija (povijesti, sjećanja, javnosti, prostora, grada ...).” Zarez. 9. 10. 2014. Web. 10. 10. 2021. $<$ https://arspublicae.tumblr.com/post/100263228249/zabludovsky-bi-to-volioakcije-u-javnom/amp>

Protrka Štimec, Marina. Politike autorstva. Kanon, zajednica i pamćenje u novijoj hrvatskoj književnosti. Zagreb: SNL, 2019.

Šišović, Davor. "Nazorologija." Blog Stara Bookaleta. 29. 05. 2007. Web. 10. 10. 2021. <https://blog.dnevnik.hr/bookaleta/2007/05/1622702770/nazorologija. html?page $=$ blog\&id $=1622702770 \&$ subpage $=0 \&$ subdomain $=$ bookaleta $>$

Uskoković, Sandra. Anamnesis. Dijalozi umjetnosti u javnom prostoru. Zagreb: UPI-2M Plus, 2018.

Zorica, Željko. Usnuli čuvari grada Zagreba ili Fantastični bestijarij. Zagreb: AGM, 1996.

Zorica, Željko. Digitalizacija spomeničke baštine i njena komercijalna eksploatacija. Dom omladine Beograda, Klub DOB, Beograd. 26. 11. 2011. Performance.

Zorica, Željko. "Digitalization of Monumental Heritage and Its Commercial Exploitation.” Youtube. Uploaded by QueerZagreb. 10. 3. 2011. <https://www. youtube.com/watch?v=FIGB8nA-a48\&feature=emb_title>

Zorica, Željko. “Događaj u Oporovcu.” Vimeo. Uploaded by Domino. 10. 2.2012. $<$ https://vimeo.com/36546227>

\section{Javno uprizarjanje avtorstva: spominski rituali v neoavantgardnih projektih Zorice-Zabludovskega}

Ključne besede: vizualna umetnost / post-avantgarda /performans / kulturni angažma / javne komemoracije / kolektivni spomin / Zorica, Željko

Umetniški intermedijski in interdiskurzivni projekti ter uprizoritveni dogodki na umetniškem odru, katerih avtorja sta Željko Zorica in njegov namišljeni soavtor, "paleoantropolog, demonolog, igralec kart in pivec vina, dr. Hans Christian Zabludovsky«, temeljijo na spominskih praksah, ki sta jih uveljavili zgodovinska znanost in kulturologija. Dogodki se sklicujejo na mehanizme proizvodnje zgodovine, preizprašujejo ustvarjalne procese ter vrednotijo izmuzljiv in zapleten odnos med kolektivnim spominom, politično sfero, literaturo in zgodovino. Knjige in umetniški performansi Zorice-Zabludovskega (postavitev spominskih plošč v Parizu, Zagrebu in Oporovcu) postavljajo pod 
vprašaj "družbeno imaginarno " kot temeljno referenco zgodovinopisnega in kritičnega dela, ki dokazuje, da teoretično in politično zavedna umetnost ne krni nujno estetskega doživetja. Članek analizira njuna dela kot izraz transgresivne narave post-avantgardnih umetniških praks in kot podvige, ki razkrivajo temeljni odnos med umetnostjo, literaturo, zgodovino in javnim prostorom.

1.01 Izvirni znanstveni članek / Original scientific article UDK 7.038.531:316.7

DOI: https://doi.org/10.3986/pkn.v44.i3.10 